\title{
The Association of MHC Molecules with COVID-19
}

\section{MHC Molekülleri ve COVID-19 İlișkisi}

\author{
Süleyman Rüștü OG̃UZ(İD)
}

Division of Medical Biology and Genetic, Demirog̃lu Bilim University, İstanbul, Turkey

Cite this article as: Oğuz SR. The association of MHC molecules with COVID-19. FLORA 2021;26(4):565-72.

\begin{abstract}
Novel "SARS-CoV-2", has approximately 30 kb genome and belongs to the "Betacoronavirus type". "SARS-CoV-2" codes several structural "spike (S) protein", "envelope (E) protein", "membrane (M) protein", "nucleocapsid (N) protein" and nonstructural proteins like the other coronaviruses. Various studies on SARS-CoV suggest that both humoral and celluler immune responses play a role in defense against this virus. "Major histocompatibility complex (MHC)" molecules have an important role in cellular and humoral immune response, various autoimmune diseases and rejection mechanisms. These properties of MHC molecules emphasizes the importance of regulated "MHC expression"for the control of the immune response. The defects in the expression of "MHC molecules" may result in severe immunopathologic consequences. "CD8+ T cells" are the main effectors in antiviral immunity. "Cytotoxic CD8+ Tlymphocytes" responses are crucial for initial viral clearance and immunologic memory. Heterogeneity in CD8+ T cell responses to SARS-CoV-2 may be associated with the capacity to recognize Class I HLA antigens, and genetic susceptibility to viral infections may be associated with HLA haplotypes. The strongest immunogenic epitopes of spike glycoproteins for B and T cells would bind HLA Class I molecules and these epitopes could be used when designing vaccine candidates against SARS-CoV-2. The relation of 'SARS-Cov-2 with "HLA locus in $M H C^{\prime \prime}$ region was investigated in the present review.
\end{abstract}

Key Words: SARS-CoV-2; MHC; HLA; COVID-19

öz

MHC Molekülleri ve COVID-19 îlișkisi

Süleyman Rüștü OG̃UZ

Tıbbi Biyoloji ve Genetik Bölümü, Demirog̃lu Bilim Üniversitesi, İstanbul, Türkiye

SARS-CoV-2 Betacoronavirus cinsine aittir ve yaklaşık 30 kb büyüklüğünde bir genoma sahiptir. Diğer koronavirüsler gibi, çoklu yapısal "spike (S) proteini, zarf (E) proteini, membran (M) proteini ve nükleokapsid (N)" ve yapısal olmayan proteinleri kodlar. SARS-CoV ile ilgili çeşitli çalışmalar, bu virüse karşı savunmada hem humoral hem de hücre aracılı bağışıklık tepkimelerinin rol oynadığını düşündürmektedir. Klasik büyük doku uygunluk kompleksi (MHC) molekülleri hücresel ve humoral bağışıklık yanıtında, çeşitli otoimmün bozukluklarda ve doku organ transplant reddinde önemli rol oynarlar. MHC sınıf I ve sınıf II'nin tüm bu özellikleri, sağlık ve hastalık durumunda bağısıılık yanıtının kontrolü için doğru şekilde düzenlenmiş MHC ekspresyonunun önemini vurgulamaktadır. MHC moleküllerinin

Received/Geliș Tarihi: 14/02/2021 - Accepted/Kabul Ediliș Tarihi: 05/09/2021

${ }^{\circ}$ Copyright 2021 by Flora. Available on-line at www.floradergisi.org. 
ekspresyonlarındaki kusurlar, ciddi immünopatolojik sonuçlara yol açabilirler. CD8+ T hücreleri, infekte olmuş hücrelerin yüzeyinde MHC sınıf I tarafından sunulan virüsten türetilmiş kısa peptitleri tanıyan antiviral bağışıklıktaki temel efektörlerdir. Sitotoksik CD8+ T lenfosit yanıtları, başlangıç viral klerensi ve immunolojik hafıza için çok önemlidir. SARS-CoV-2'ye karşı CD8+ T hücre yanıtlarındaki heterojenlik, Sınıf I HLA moleküllerini tanıma kapasitesi ile, viral infeksiyonlara genetik yatkınlık ise HLA haplotipleri ile ilişkili olabilir. Spike proteinlerinin B ve T hücreler için en kuvvetli immunojenik epitopları, HLA Sınıf I molekülleri ile bağlanabilir ve SARS Cov-2'ye karşı aşı dizaynında kullanılabilirler. Bu derlemede SARS-CoV-2 ile MHC bölgesindeki HLA lokus ilişkisi incelendi.

Anahtar Kelimeler: SARS-COV-2; MHC; HLA; COVID-19

\section{INTRODUCTION}

An unexplained pneumonia endemic which emerged in December 2019 was reported to the "World Health Organization (WHO)". This pneumonia endemic named "COVID-19" was recorded as a new coronavirus ${ }^{[1,2]}$. It is supposed that we have to live with this virus for a long time. Although much has been learned about the "COVID-19" disease and its pathogenesis as a result of research by scientists, it still remains a mystery. It usually causes mild respiratory infections in humans ${ }^{[3,4]}$. Some coronavirus infections have resulted in deadly endemics, including "Severe Acute Respiratory Syndrome (SARS)" and "Middle East Respiratory Syndrome (MERS)". It has been disclosed that these diseases are caused by "zoonotic coronaviruses" belonging to the "Betacoronavirus" type. "SARS-CoV" originated in Southern China. Worldwide, more than eight thousand cases of "SARS" have been reported, including 774 related deaths. The estimated case death rate has been reported between 14\% and $15 \%[5]$. The first "MERS" case appeared in 2012 in Saudi Arabia. A total of 2.494 cases of infection were reported, including 858 related deaths. The estimated case-mortality rate is $34.4 \%[6]$.

The new "SARS-CoV-2", encodes multiple structural and nonstructural proteins such as "spike (S) protein", "envelope (E) protein", "membrane (M) protein", and "nucleocapsid (N) protein. It has been associated with several studies that both humoral and cell-mediated immune reactions have an important role in immunity to this virus. In previous studies, it has been shown that the antibody response against the $\mathrm{S}$ protein in rat models exposed to SARS-CoV protein was highly immunogenic and protected from infection ${ }^{[7-9]}$. In addition, researchers have reported in multiple studies that patients specifically infected with SARS-CoV had a greater number of augmented antibodies to the $\mathrm{N}$ protein of SARS$\mathrm{CoV}$ and a higher antibody response $e^{[10-12]}$. As a result of the studies, it has been revealed that the antibodies against the $\mathrm{N}$ protein increased in patients infected with SARS-CoV were higher than those in uninfected patients, and that the antibody response was short-lived in recovered SARS-CoV patients ${ }^{[10-16]}$. T cell reactions were predominant and longest lasting against $\mathrm{S}$ and $\mathrm{N}$ proteins ${ }^{[17,18]}$. The host must be healthy and have a suitable genetic structure (HLA) for the emergence of specific antiviral immunity and the development of an endogenous protective immune reaction during incubation and in the non-severe stage of the disease. It is known that genetic differences contribute to immunity against pathogens ${ }^{[19]}$. The close interaction of the "SARS-CoV-2" virus with the immune system plays an important role in humoral immunity.

"Major Histocompatibility Complex (MHC) class I and II antigens" down-regulate limiting antigen presentation and inhibiting T-cell-mediated immune reactions ${ }^{[20]}$. "MHC class I" antigens are key in antigen presentation and initiation of the adaptive "CD8+ T cell" response ${ }^{[2-5]}$. The "cytotoxic CD8+ T lymphocyte" response is great importance for initial viral clearance and immunological memory. Heterogeneity in "CD8+ T cell" responses, the recognition capacity of "Class I MHC" molecules and genetic susceptibility to viral infections are associated with Human Leucocytes Antigen (HLA) haplotypes ${ }^{[6]}$.

\section{HLA and COVID-19}

"HLA" genes which have thousands of different alleles emerging with the combinations of multiple single nucleotide polymorphisms (SNP), are known to demonstrate the highest polymorphism in MHC complexes in our genome. This 
unique polymorphism level selected in genetic variation of possibly thousands of generations of natural selection is the most commonly accepted model in HLA molecular evolution. Such a model supports the assumption that heterozygotic individuals might more easily adapt with the pathogen rich environments compared with the homozygotic individuals, and different HLA molecules will create an immunity reaction by presenting the peptides belonging to pathogens to $\mathrm{T}$ cells ${ }^{[21]}$. This type of population level selection indicates that the "HLA allele" frequency distribution is higher than expected in neutral evolution, and the heterogeneity of most populations is 85\% and 95\% at each HLA locus.

The "HLA complex" is best known for T cell recognition against foreign antigens. Therefore, it is known that infectious diseases and viruses such as "Chikungunya", "Chagas [22]", "dengue","influenza A (H1N1)" and "tuberculosis [23]", "hepatitis B virus (HBV)", "hepatitis C virus $(\mathrm{HCV})^{[24,25] \text { ", }}$ "human immunodeficiency virus (HIV)", "human papilloma virus (HPV) have been associated with different genetic polymorphisms of HLA ${ }^{[26-28]}$.

The HLA genetic profile might have partly influenced the way of the immune response to an invading foreigner because HLA alleles may exhibit worldwide varying regional frequencies and HLA alleles may exhibit different peptide binding properties $^{[29-31]}$.

HLA alleles which are playing critical role of viral antigen presentation have been suggested to be associated with the disease severity, and with a different viral sensitivity. Some HLA types (HLA-A*02:05) in HIV-1 infection may decrease the seroconversion risk. Some HLA alleles (HLA-A*02:07, HLA-B*51) in Etnical Thai de Dank virus infections have been found associated with the secondary disease severity $[32,33]$.

The genetic variability in "HLA class I" locus may affect the sensitivity and severity of disease caused by "SARS-CoV-2"[14,16].

Thirty-seven possible SARS cases, 28 possible SARS patients with high fever (later were excluded), SARS coronavirus exposed or possibly exposed 101 noninfected health workers were included and 190 normal healthy unrelated in- dividuals were also used as control group in a study conducted in Taiwan. Class I-II HLA allele typing in all cases were performed using the "PCR-SSOP" method. First, the infected SARS patients, and high-risk health workers groups were analysed, and HLA-B*46:01 $(O R=2.08, p=$ 0.04, $\mathrm{Pc}=\mathrm{ns})$, and HLA-B*54:01 $(\mathrm{OR}=5.44$, $\mathrm{p}=0.02, \mathrm{Pc}=\mathrm{ns})$ were detected as the most possible factors supporting the SARS coronavirus infection. Only "severe cases" from infected "possibly SARS" patient group were selected and were compared with the high-risk health workers group, and severity of the disease was increased in individuals who had HLA-B*46: 01 genotype ${ }^{[32]}$.

A study of SARS-CoV2-positive individuals in a Biobank population in a UK in silico analysis also identified that DRB1*15:01 and DQB1*06:02 were associated with an increased probability of 'SARS-CoV-2" positivity (34). These observations support Paulton et al.'s study that has shown a significant association with HLA-DQB1*06 (53\% vs. $36 \% ; p<.012$; OR 1.96; 95\% CI 1.94-3.22) and infection ${ }^{[35]}$.

Pisanti et al. have demonstrated that the frequencies of the most common Italian haplotypes in regions by using the data of the "Italian Bone Marrow Donors". All donors were typed HLA$\mathrm{A},-\mathrm{B},-\mathrm{C}$, and -DRB1 "high resolution". Pearson's correlation analysis was used between the regional haplotype estimation frequency in Italian population with the COVID-19 incidence, and mortality. Researchers found that the commonly detected two "HLA haplotypes" in population were HLA-A *01:01g, -B*08:01g, -C*07:01g, -DRB1*03:01g, and HLA-A*02:01g -B*18:01g -C*07:01g, -DRB1*11:04g, there was a regional distribution corresponding similar to COVID-19, and showed positive (decreasing the sensitivity), and negative (suggesting the protection) significant correlation with COVID-19 incidence, and mortality, respectively (36). A comprehensive silico analysis (in-silico $\mathrm{T}$ cells epitopes- epitope binding analysis) of the viral peptide-MHC class I binding affinity in 145 HLA-A, -B, and -C genotypes for all SARS CoV-2 peptides performed by Salvat et al. ${ }^{[3]}$. Cross protective immunity potential which is enabled by exposure of four common 
human coronaviruses was also investigated in that study. SARS-CoV-2 proteome was successfully sampled, and presentation with HLA alleles was performed. HLA-B*46:01 was found to have the least number of estimated binding peptides for SARS-CoV-2. This finding suggests, as shown for SARS in a previous study for individuals with this allele, that they might be particularly defenseless against COVID-19 ${ }^{[32]}$. However, HLA-B*15:03 was suggested to have a huge capacity for presenting highly preserved SARS-CoV-2 peptides which is commonly shared in human coronaviruses, and that might have cross protection and might enable $\mathrm{T}$ cell-based immunity ${ }^{[38,39]}$

HLA antigens have an important role in the immune system by determining the peptide repertoire presented to the $\mathrm{T}$ cell compartment. With its dense genetic polymorphisms, this system confers strong variability in vaccine-induced immune responses and can complicate the selection of vaccine candidates as the distribution and frequencies of HLA alleles are highly variable among different ethnic groups ${ }^{[40]}$.

HLA heterozygosity has been associated with variations in vaccine-induced immunity against various pathogens. HLA homozygosity can alter immune responses to vaccines. For example, HLA homozygosity is associated with lower measles virus-specific IgG levels after a single dose of MMR vaccine (live weakened viruses) ${ }^{[41]}$. However, in the case of the rubella vaccine, homozygosity at the HLA-DPB1 locus after two doses of rubella-containing vaccine has been associated with increased levels of rubella virus-specific $\operatorname{IgG}$, an effect driven by a common DPB1*04:01 allele ${ }^{[42]}$.

Liu and et al. have shown that HLA-B*40:01 and "HLA-B44" are potentially associated with non-response after immunization with the novel RV3 vaccine in Chinese infants ${ }^{[43]}$.

HLA- DRB1,-DQB1, -DPB1, have been shown to be associated with interindividual variance in the hepatitis $\mathrm{B}(\mathrm{HB})$ vaccine response. DPB1*04:02 was shown as independent predictor of the $\mathrm{HB}$ vaccine response in Korean population ${ }^{[44]}$. Ovsyannikova et al. have suggested that rubella vaccine-induced adaptive immune responses are significantly influenced by polymorphisms of HLA class I and II alleles, particularly $A^{*} 31: 01$, $\mathrm{B}^{*}$ 27:05, and DPB1*04:01 ${ }^{[45]}$. In a large cohort (2.506 healthy immunized subjects), it has been shown that suggestive associations between several allelic variants of the HLA-B, -DQB1 and -DRB1 loci and measles vaccine-induced neutralizing antibodies. HLA-B*57:01, HLA-DQB1*06:02, and DRB1*15:05 alleles were associated with variation in antibodies ${ }^{[46]}$. "Multiple epitope-based peptide "epitopes capable of activating a number of "HLA-restricted T-cell" features can be combined with "B-cell epitopes" to form a vaccine. This form of vaccine produces specific immune responses ${ }^{[47]}$. Epitope-based vaccines were found to induce stronger responses than whole protein vaccines $^{[48]}$.

Recently developed technological tools such as computation that could gain and put together data from in vitro or "mass spectrometry assays" might get to the prediction of peptide-binding affinities of HLA molecules ${ }^{[49]}$. The methods that could be used for the identification of viral epitopes might be considered as good candidates for peptide-based vaccines, including against SARS-CoV-2 and HIV-1, Ebola virus ${ }^{[43,50-52]}$

New vaccines and tools to monitor T/B cells' response to COVID-19 have been developed using Bioinformatics studies. In this context, bioinformatics tools are highly useful for the driven "SARSCoV-2 HLA-class I and II epitopes". Kyotani et al. have shown that HLA-class I ( $\mathrm{n}=781)$ and HLA-class II $(n=418)$ epitopes are known to be common among SARS-CoV-2 and SARS$\mathrm{CoV}$. The four epitopes have been established as follows; S1060-1068, S1220-1229, N222-230" and "N315-324 SARS-CoV-2". The high affinity epitopes for "HLA-A*02:06, HLA-B*52:01" and "HLA-C*12:02" have been predicted to originate from SARS-CoV-2. S1060-1068 epitopes. These epitopes can cover $83.8 \%$ of Japanese individuals according to their allele frequencies. Bioinformatics screening identified numerous potential $\mathrm{T}$ cell epitopes, some of which may include "SARS-CoV". Kyotani et al. have suggested that these findings could contribute to the design of vaccines (DNA or RNA, inactivated viral or peptide vaccines), as well as monitoring the immune response of SARS-CoV2-infected patients ${ }^{[54]}$. 
Candidate $\mathrm{T}$ cell epitopes could be identified by the prediction of "HLA binding affinity". For the selection of peptide, "HLA binding" affinity of "500 nM" is accepted as a threshold. The percentage of peptides predicted to bind with affinities of $500 \mathrm{nM}$ varies by HLA allele. For example, "dengue virus-derived" peptides only $0.3 \%$ were predicted to bind "HLA A*01:01", whereas 5\% were predicted for " $A * 02: 01$ ". Absolute binding capacity is accepted as a better predictor of immunogenicity in several studies ${ }^{[55]}$. "Immune Epitope Database" (IEDB) is a tool to analyze epitopes and has revealed that predictive efficacy is increased using "allele-specific affinity thresholds"[56].

Barquera $\mathrm{R}$ et al. have studied to predict the peptide-binding affinity of each HLA antigen to all possible peptides (9-mer HLA Class I) and (13-mer for HLA Class II) derived from all viral proteins. The number of viral peptides included in the study for HLA "Class I/Class II-binding" predictions were 7065/7061 for "SARSCoV-1", 7089/7084 for "SARS-CoV-2", IEDP, and "Analysis Resource "virtual machine" image was also used for peptide-HLA-binding affinity predictions in this study ${ }^{[57,58]}$. For each epitope sequence predicted to be an "HLA binder", the predicted IC50 value (half the maximum inhibitory concentration, measured in molar concentration $\mathrm{nM}$ units) and percentile rank (unitless) for peptide binding to MHC molecules were calculated using the "NetMHCIIpan method". This method predicts the specific subsequence that an HLA antigen recognizes (binding core) as well as its binding affinity using a neural network-based model ${ }^{[59]}$.

Binding affinities between 438 HLA antigens have been characterized using a bioinformatics method derived from the entire SARS-CoV-2 proteome ${ }^{[60]}$. Overall allelic frequency distributions have been analyzed, and statistical modeling has been used to hypothetically identify the HLA proteins that bind these viral peptides strongest and weakest ${ }^{[60]}$.

Barquera $\mathrm{R}$ et al. have classified the binding predictions as strong (IC50 $\leq 50 \mathrm{nM}$ ), regular (50 $\mathrm{nM}<\mathrm{IC50} \leq 500 \mathrm{nM})$ and weak $(500 \mathrm{nM}<\mathrm{IC5} 0$ $\leq 5000 \mathrm{nM}$ ) binders for Class I, and strong (IC50 $\leq 50 \mathrm{nM})$, regular $(50 \mathrm{nM}<\mathrm{IC50} \leq 1000 \mathrm{nM})$ and weak (1000 nM <IC50 $\leq 5000 \mathrm{nM})$ binders for Class II. Any peptide-binding prediction affinity above $5000 \mathrm{nM}$ has been considered as a non-binder ${ }^{[58]}$. Strongest binders are those predicted to bind at least 100 viral peptides with strong affinity and weakest binders were those predicted to bind weakly or not at all to more than $99 \%$ of viral peptides.

Twenty eight HLA antigen were classified as strongest and 144 HLA as weakest have been reported in all Class I and II antigens.

$A^{*} 02: 11$ and $A^{*} 02: 22$ are strongest HLA-A binders for Class I. They bind more than 200 peptides with high affinity and are also weak or non-binders for the lowest proportion of peptides $(<93 \%)$. B*15:03 is predicted to bind more than 200 peptides with strong affinity. $B * 35: 10$ and $B * 15: 17, * 15: 25, * 15: 39$ are the other strongest binders.

Among the DR alleles, DRB1*01:01 is strong binder for as many as 719 peptides, followed by DRB1*10:01 (358 peptides) and DRB1*01:04. Frequencies of the strongest and weakest HLA binders having been different among populations from different geographic regions is the more interesting findings in the study ${ }^{[59-62]}$.

\section{CONCLUSION}

After all these studies, while the detailed clinical picture of the COVID-19 pandemic continues, there are still important questions to be answered about the importance of genetic variability in the immune response against SARS-CoV-2. The responses to some of these questions may be provided with "HLA typing" in severe cases particularly with no significant risk factor. In the near future the identification of "epitope" and the prediction of "HLA peptide-binding" could be useful for research of immunogenetic to understand the behaviour of specific HLA alleles in pathogen-rich environments.

HLA genes do not explain all the variations in immune responses to vaccines in the population. The vaccine response is thought to be controlled by a multiple genetic locus, which is consistent with the immune response network theory. 


\section{CONFLICT of INTEREST}

None of the author had conflict of interest.

\section{REFERENCES}

1. Zhou P, Yang XL, Wang XG, Hu B, Zhang L, Zhang W, et al. $A$ pneumonia outbreak associated with a new coronavirus of probable bat origin. Nature 2020;579:270-3.

2. Wang C, Horby PW, Hayden FG, Gao GF. A novel coronavirus outbreak of global health concern. Lancet 2020;395:4703.

3. Trilla A, Trilla G, Daer C. The 1918 "Spanish flu" in Spain. Clin Infect Dis 2008;47(5):668-73.

4. Guan WJ, Ni ZY, Hu Y, Liang WH, Ou CQ, He JX, et al. Clinical Characteristics of Coronavirus Disease 2019 in China. N Engl J Med 2020;382(18):1 708-20.

5. World-Health-Organization (WHO). Update 49-SARS case fatality ratio, incubation period. Accessed date: 31 January 2020. Available from: https://www.who.int/csr/sars/ archive/2003_05_07a/en/

6. World Health Organization (WHO). Middle East respiratory syndrome coronavirus (MERS-CoV). Accessed on 31 January 2020. Available from: https://www.who.int/emergencies/mers-cov/en/

7. Yang $Z Y$, Kong WP, Huang $Y$, Roberts $A$, Murphy $B R$, Subbarao $K$, et al. DNA vaccine induces SARS coronavirus neutralization and protective immunity in mice. Nature 2004;428:561-4.

8. Deming $D$, Sheahan $T$, Heise $M$, Yount $B$, Davis $N$, Sims $A$, et al. Vaccine efficacy in senescent mice challenged with recombinant SARS-CoV bearing epidemic and zoonotic spike variants. PLoS Med 2006;3(12):e525.

9. Graham RL, Becker MM, Eckerle $L D$, Bolles M, Denison MR, Baric RS. A live, impaired-fidelity coronavirus vaccine protects in an aged, immunocompromised mouse model of lethal disease. Nat Med 2012;18(12):1820-6.

10. Lin $Y$, Shen $X$, Yang RF, Li YX, Ji YY, He YY, et al. Identification of an epitope of SARS-coronavirus nucleocapsid protein. Cell Res 2003;13(3):141-5.

11. Wang J, Wen J, Li J, Yin J, Zhu Q, Wang H, et al. Assessment of immunoreactive synthetic peptides from the structural proteins of severe acute respiratory syndrome coronavirus. Clin Chem 2003;49(12):1989-96.

12. Liu X, Shi Y, Li P, Li L, Yi Y, Ma Q, et al. Profile of antibodies to the nucleocapsid protein of the severe acute respiratory syndrome (SARS)-associated coronavirus in probable SARS patients. Clin Diagn Lab Immunol 2004;11(1):227-8.

13. Tang F, Quan Y, Xin ZT, Wrammert J, Ma MJ, Lv H, et al. Lack of peripheral memory $B$ cell responses in recovered patients with severe acute respiratory syndrome: $A$ six-year follow-up study. J Immunol 2011;186(12):7264-8.

14. Ng OW, Chia A, Tan AT, Jadi RS, Leong HN, Bertoletti $A$, et al. Memory $T$ cell responses targeting the SARS coronavirus persist up to 11 years post-infection. Vaccine 2016;34(17):2008-14.
15. Peng $H$, Yang $L T$, Wang $L Y, L i$ J, Huang J, Lu ZQ, et al. Longlived memory $T$ lymphocyte responses against SARS coronavirus nucleocapsid protein in SARS-recovered patients. Virology 2006;351(2):466-75.

16. Fan $Y Y$, Huang $Z T$, Li L, Wu MH, Yu T, Koup RA, et al. Characterization of SARS-CoV-specific memory T cells from recovered individuals 4 years after infection. Arch Virol 2009;154(7):1093-9.

17. Li CKF, Wu H, Yan H, Ma S, Wang L, Zhang M, et al. $T$ cell responses to whole SARS coronavirus in humans. I Immunol 2008;181(8):5490-500.

18. Channappanavar R, Fett C, Zhao I, Meyerholz DK, Perlman S. Virus-specific memory CD8 $T$ cells provide substantial protection from lethal severe acute respiratory syndrome coronavirus infection. J Virol 2014;88(19):11034-44.

19. Paces /, Strizova Z, Smrz D, Cerny J. COVID-19 and the Immune System. Physiol Res 2020;69(3):379-88.

20. Kumar S, Nyodu R, Maurya VK, Saxena SK. Host Immune Response and Immunobiology of Human SARS-CoV-2 Infection. In: Saxena S. (eds). Coronavirus Disease 2019 (COVID-19). Medical Virology: From Pathogenesis to Disease Control. Springer, 1th ed. Singapore, 2020:43-53.

21. Sanchez-Mazas A. HLA studies in the context of coronavirus outbreaks. Swiss Med Wkly 2020;150:w20248.

22. Cruz-Robles $D$, Reyes PA, Monteón-Padilla VM, Ortiz-Mu niz AR, Vargas-Alarcón G. MHC class I and class II genes in Mexican patients with Chagas disease. Hum Immunol 2004;65:60-5.

23. Soto $M E$, Vargas-Alarcón $G$, Cicero-Sabido $R$, Ramírez $E$, Alvarez-León E, Reyes PA. Comparison distribution of HLA-B alleles in Mexican patients with takayasu arteritis and tuberculosis. Hum Immunol 2007;68:449-53.

24. Mosaad YM, Farag RE, Arafa MM, Eletreby S, El-Alfy HA, Eldeek $B S$, et al. Association of human leucocyte antigen Class I (HLA-A and HLA-B) with chronic hepatitis C virus infection in Egyptian patients. Scand I Immunol 2010;72:548-53.

25. Koziel MJ, Dudley D, Afdhal N, Grakoui A, Rice CM, Choo $Q L$, et al. HLA class I-restricted cytotoxic T lymphocytes specific for hepatitis $C$ virus. Identification of multiple epitopes and characterization of patterns of cytokine release. I Clin Invest 1995;96(5):2311-21.

26. Bravo MJ, Colmenero Jde D, Alonso A, Caballero A. HLA-B*39 allele confers susceptibility to osteoarticular complications in human brucellosis. J Rheumatol 2003;30(5):1051-3.

27. Hendel H, Caillat-Zucman S, Lebuanec H, Carrington M, O'Brien S, Andrieu JM, et al. New class I and II HLA alleles strongly associated with opposite patterns of progression to AIDS. J Immunol 1999;162(11):6942-6.

28. Keicho N, Hijikata M. Genetic predisposition to diffuse panbronchiolitis. Respirology 2011;16(4):581-8.

29. Solberg OD, Mack SJ, Lancaster AK, Single RM, Tsai Y, Sanchez-Mazas A, et al. Balancing selection and heterogeneity across the classical human leukocyte antigen loci: a meta-analytic review of 497 population studies. Hum Immunol 2008;69(7):443-64. 
30. Buhler S, Sanchez-Mazas A. HLA DNA sequence variation among human populations: molecular signatures of demographic and selective events. PLoS One 2011;6(2):e14643.

31. Takeshita LYC, Jones AR, Gonzalez-Galarza FF, Middleton D. Allele frequencies database. Transfus Med Hemother 2014;41(5):355-2

32. Lin M, Tseng HK, Trejaut JA, Lee HL, Loo JH, Chu CC, et al. Association of HLA class I with severe acute respiratory syndrome coronavirus infection. BMC Med Genet 2003;4:9.

33. Stephens HAF, Klaythong $R$, Sirikong M, Vaughn DW, Green $S$, Kalayanarooj $S$, et al. HLA-A and $-B$ allele associations with secondary dengue virus infections correlate with dis ease severity and the infecting viral serotype in ethnic Thais. Tissue Antigens 2002;60(4):309-18.

34. Kachuri L, Francis SS, Morrison M, Bossé Y, Cavazos TB, Rashkin SR, et al. The landscape of host genetic factors involved in infection to common viruses and SARS CoV-2. medRxiv 2020;10.1101/2020.05.01.20088054.

35. Paulton $K$, Wright $P$, Hughes $P$, Savic S, Smith MW, Guiver $M$, et al. A role for human leucocyte antigens in the susceptibility to SARS-Cov-2 infection observed in transplant patients. Int J Immunogenet 2020;47(4):324-8.

36. Pisanti S, Deelen J, Gallina AM, Caputo M, Citro M, Abate $M$, et al. Correlation of the two most frequent HLA haplotypes in the Italian population to the differential regional incidence of Covid-19. J Transl Med 2020;18(1):352.

37. Salvat R, Moise L, Balley-Kellogs C, Griswold KE. A High Throughput MHC II Binding Assay for Quantitative Analysis of Peptide Epitopes. J Vis Exp 2014;(85):51308.

38. Nguyen A, David JK, Maden SK, Wood MA, Weeder BR, Nellore $A$, et al. Human leukocyte antigen susceptibility map for severe acute respiratory syndrome coronavirus 2. I Virol 2020;94(13):e00510-20.

39. Iturrieta-Zuazo I, Rita CG, Garcia-Soidán A, de Malet Pintos-Fonseca A, Alonso-Alarcón N, Pariente-Rodríguez $R$, et al. Possible role of HLA class-I genotype in SARS-CoV-2 infection and progression: A pilot study in a cohort of COVID-19 Spanish patients. Clin Immunol 2020;219:108572.

40. Oyarzun P, Kashyap M, Fica V, Salas-Burgos A, Gonzalez-Galarza FF, McCabe A, et al. A proteome-wide immunoinformatics tool to accelerate $t$-cell epitope discovery and vaccine design in the context of emerging infectious diseases: an ethnicity-oriented approach. Front Immunol 2021;12:598778.

41. Sauver JL, Ovsyannikova IG, Jacobson RM, Jacobsen SI, Vierkant RA, Schaid DJ, et al. Associations between human leukocyte antigen homozygosity and antibody levels to measles vaccine. J Infect Dis 2002;185:1545-49.

42. Kennedy RB, Ovsyannikova IG, Vierkant RA, Jacobson RM, Poland GA. Effect of human leukocyte antigen homozygosity on rubella vaccine-induced humoral and cell-mediated immune responses. Hum Immunol 2010;71:128-35.

43. Liu $Y$, Guo T, Yu Q, Zhang H, Du J, Zhang $Y$, et al. Association of human leukocyte antigen alleles and supertypes with immunogenicity of oral rotavirus vaccine given to infants in China. Medicine (Baltimore) 2018;97(40):e12706.
44. Chung $S$, Roh EY, Park B, Lee Y, Shin S, Yoon JH, et al. GWAS identifying HLA-DPB1 gene variants associated with responsiveness to hepatitis $B$ virus vaccination in Koreans: Independent association of $H L A-D P B 1 * 04: 02$ possessing rs1042169 G-rs9277355 C-rs9277356 A. J Viral Hepat 2019;26(11):1318-29.

45. Ovsyannikova IG, Pankratz VS, Larrabee BR, Jacobson RM, Poland GA. HLA genotypes and rubella vaccine immune response: additional evidence. Vaccine 2014;32(33):4206-13.

46. Ovsyannikova IG, Schaid DJ, Larrabee BR, Haralambieva IH, Kennedy RB, Poland GA. A large population-based association study between HLA and KIR genotypes and measles vaccine antibody responses. PLoS One 2017;12(2):e0171261.

47. Lim HX, Lim J, Poh CL. Identification and selection of immunodominant $B$ and $T$ cell epitopes for dengue multi-epitopebased vaccine. Med Microbiol Immunol 2021;210(1):1-11.

48. Kao DJ, Hodges RS. Advantages of a synthetic peptide immunogen over a protein immunogen in the development of an anti-pilus vaccine for Pseudomonas aeruginosa. Chem Biol Drug Des 2009;74:33-42.

49. Gfeller D, Bassani-Sternberg M. Predicting antigen presentation - what could we learn from a million peptides? Front Immunol 2018;9:1716.

50. Lee $\mathrm{CH}$, Koohy $\mathrm{H}$. In silico identification of vaccine targets for 2019-nCoV. F1000Res 2020;9:145.

51. Ahmed SF, Quadeer AA, McKay MR. Preliminary identification of potential vaccine targets for the COVID-19 coronavirus (SARS-CoV-2) based on SARS-CoV immunological studies. Viruses 2020;12(3):254.

52. Abdulla F, Adhikari UK, Uddin MK. Exploring $T$ \& B-cell epitopes and designing multi-epitope subunit vaccine targeting integration step of HIV-1 lifecycle using immunoinformatics approach. Microb Pathog 2019;137:103791.

53. Jain S, Baranwal M. Conserved peptide vaccine candidates containing multiple Ebola nucleoprotein epitopes display interactions with diverse HLA molecules. Med Microbiol Immunol 2019;208(2):227-38.

54. Kiyotani K, Toyoshima Y, Nemoto K, Nakamura Y. Bioinformatic prediction of potential T cell epitopes for SARS-Cov-2. J Hum Genet 2020;65(7):569-75.

55. Paul S, Weiskopf D, Angelo MA, Sidney J, Peters B, Sette A. HLA class I alleles are associated with peptide-binding repertoires of different size, affinity, and immunogenicity. I Immunol 2013;191(12):5831-9.

56. Wang $P$, Sidney J, Kim $Y$, Sette $A$, Lund $O$, Nielsen $M$, et al. Peptide binding predictions for HLA DR, DP and DQ molecules. BMC Bioinformatics 2010;11:568

57. Moutaftsi $M$, Peters B, Pasquetto V, Tscharke DC, Sidney J, Bui $\mathrm{HH}$, et al. A consensus epitope prediction approach identifies the breadth of murine $T(C D 8+)$-cell responses to vaccinia virus. Nat Biotechnol 2006;24(7):817-19.

58. Charonis S, James LM, Georgopoulos AP. In silico analysis of the binding affinities of antigenic epitopes of vaccines administered to gulf war veterans to specific HLA class II alleles protective for gulf war illness. I Neurol Neuromed 2019;4(5): 23-30. 
59. Barquera $R$, Collen E, Di D, Buhler S, Teixeira J, Llamas B, et al. Binding affinities of 438 HLA proteins to complete proteomes of seven pandemic viruses and distributions of strongest and weakest HLA peptide binders in populations worldwide. HLA 2020;96(3):277-98.

60. Pierini F, Lenz TL. Divergent allele advantage at human $\mathrm{MHC}$ genes: signatures of past and ongoing selection. Mol Biol Evol 2018;35(9):2145-58.

61. Manczinger $M$, Boross $G$, Kemény $L$, Müller $V$, Lenz TL, Papp B. Pathogen diversity drives the evolution of generalist MHC-II alleles in human populations. PLoS Biol 2019;17(1):e3000131.
62. Sanchez-Mazas A, Černý V, Di D, Buhler S, Podgorna E, Chevallier $E$, et al. The HLA-B landscape of Africa: signatures of pathogen-driven selection and molecular identification of candidate alleles to malaria protection. Mol Ecol $2017 ; 26(22): 6238-52$

\section{Address for Correspondence/Yazıșma Adresi}

Dr. Süleyman Rüsțü OĞUZ

Division of Medical Biology and Genetic,

Demiroğlu Bilim University,

İstanbul-Turkey

E-posta: rusduoguz@gmail.com 